\title{
Administrative and criminal penalties for a failure to register a vehicle in due time
}

\author{
Sankcje administracyjne i karne \\ za brak terminowej rejestracji pojazdu
}

\begin{abstract}
A determination of amounts of administrative monetary penalties and criminal sanctions resulting from a lack of fulfilment of some of registration obligations imposed on an owner of a vehicle is a practical problem related to the activity of the authorities keeping the vehicle register. Particular doubts are raised not by a necessity to impose a penalty, but by its amount, as well as by a possibility of waiving the penalty. Further doubts are raised by a possibility of applying a criminal liability to entities that have not fulfilled with their obligations. In the present study, the authors, using a dogmatic and legal method, analyse circum-
\end{abstract}


stances affecting the amount of the penalty, the possibility of abrogating the penalty, as well as the potential possibility of applying criminal liability.

Keywords: administrative monetary penalty; administrative liability; criminal liability; administrative obligations; exemptions from administrative monetary penalty.

Streszczenie. Wymiar pieniężnej kary administracyjnej oraz sankcji karnych wynikających z braku wykonania niektórych obowiązków ewidencyjnych ciążących na właścicielu pojazdu jest praktycznym problemem związanym z działalnością organów prowadzących ewidencję. Szczególne wątpliwości nie wywołuje konieczność wymierzenia kary, lecz jej wysokość, a także możliwość odstąpienia od wymiaru kary. Dodatkowe wątpliwości wywołuje możliwość zastosowania odpowiedzialności karnej względem podmiotów, które nie wykonały ciążących na nich obowiązków. W niniejszym opracowaniu autorzy przy zastosowaniu metody dogmatyczno-prawnej analizują okoliczności wpływające na wysokość kary, możliwość zastosowania instytucji odstąpienia od jej wymierzenia, a także potencjalna możliwość stosowania odpowiedzialności karnej.

Słowa kluczowe: administracyjna kara pieniężna; odpowiedzialność administracyjna; odpowiedzialność karna; obowiązki administracyjne; odstąpienia od nałożenia administracyjnej kary pieniężnej.

\section{Introduction}

Administrative monetary penalties, as well as offences related to an infringement of registration obligations, are not considered to be the most serious violations of the law in force. The issue of their imposition is not mentioned in headlines, nor does it constitute a mainstream of doctrinal studies ${ }^{1}$. In public administration bodies' practice, obligations to register and a lack of fulfilment of these obligations cause a number of problems, while the application of particular provisions gives rise to a number of controversies. Obligations to register and a lack of fulfilment of these

1 On the other hand, the very issue of administrative sanctions forms basis of doctrinal considerations, for example: M. Wincenciak, Sankcje w prawie administracyjnym i procedura ich wymierzania, Warszawa 2008, or a collective study: M. Stahl, R. Lewicka, M. Lewicki (eds.), Sankcje administracyjne. Blaski i cienie, Warszawa 2011. 
obligations cause a number of problems for public administration bodies often result from a divergent jurisprudence of administrative courts and higher-level bodies, and a lack of clarity of legal regulation.

In this paper, we would like to focus on legal aspects of administrative fines and penalties resulting from a failure to fulfil certain registration obligations imposed on a vehicle owner. We will highlight issues related to the mere failure to fulfil an obligation without a detailed analysis of substantive and legal grounds for this fulfilment. We will focus mainly on the aspects of imposing a penalty, a determination of its amount and a potential possibility of imposing penalties.

The problem seems interesting owing to the fact that it covers issues related to public finance law (income from imposed fines constitutes additional income for the county), administrative law and proceedings (administrative fines are imposed by way of a decision), and, in some situations, criminal law (failure to comply with registration obligations may potentially constitute an offence).

For the purpose of elaborating the issue, we have applied the dogmatic method, making use of the views of the administrative courts, common courts of law and the body of judicature, and we have also performed an exegesis of the provisions in force.

\section{Obligation to register a vehicle and notification of its disposal}

The vehicle owner has a number of obligations of a public-law nature. These are not only obligations related to maintaining the vehicle in an appropriate technical condition, consisting, inter alia, in carrying out technical inspections of the vehicle, but they are also obligations of a strictly record-keeping nature. They result primarily from the Act on Road Traffic Law ${ }^{2}$. Those obligations include, inter alia, an obligation to

2 Act of 20 June 1997 - Road Traffic Law (consolidated text: Dz.U. [Polish Journal of Laws] of 2021, poz. [item] 450 with subsequent amendments), further referred to as the RTL or the Act. 
register a vehicle which is not a new vehicle, but it is imported from the territory of a Member State of the European Union into the territory of the Republic of Poland (Article 71(7) of the RTL) and an obligation to notify a purchase or a sale of a vehicle (Article 78(2)(1) of the RTL).

It should be noted that a registration of a vehicle takes place by means of an administrative decision issued on the basis of provisions of the general administrative procedure ${ }^{3}$. The issuance of the decision is preceded by an investigation, the aim of which is to establish premises, which allow the vehicle to be registered, listed in Article 72 of the RTL. Generally, (looking at it from the perspective of the vehicle owner) a vehicle registration requires to submit documents required by law, and the public administration authority (starost) is obliged to verify them. In order to register a vehicle, it is obligatory to fulfil the statutory prerequisites. Both the doctrine and the judicature state that "if the statutory conditions are not met, i.e. if the required documents are not submitted, the vehicle cannot be registered. The said documents must not only be true in a formal sense, i.e. drawn up by the authorities or persons appointed for that purpose, but they must also be consistent with the factual state" ${ }^{4}$.

From the point of view of the discussed issues, it is necessary to emphasize that an obligation to register a vehicle is also fulfilled when an owner has effected a temporarily registered a vehicle. The Voivodeship Administrative Court in Poznań points this out, stating that "When interpreting literally the provision of Article 140mb item 1 of the Act, it should be noted that it contains the general phrase «fails to register the vehicle». Similarly, the provision of Article 71(7) of the Act also contains a general statement «fails to register the vehicle». The above means that the fine provided for in section $140 \mathrm{mb}$ para. 1 of the Act should be imposed on an entity which fails to register the vehicle in any manner

3 Act of 14 June 1960 Code of Administrative Procedure (consolidated text: Dz.U. of 2021, item 735 with subsequent amendments), further referred to as the CAP.

4 Ł. Malinowski [in:] Prawo o ruchu drogowym. Komentarz, Warszawa 2012, Art. 72, Thesis 11, eLex, also the Voivodeship Administrative Court in Gdańsk in a judgment of 23 March 2017, III SA/Gd 1101/16, Central Database of Decisions of Administrative Courts (CBOSA) at: www.orzeczenia.nsa.gov.pl/cbo/query. 
whatsoever, as provided for in Article 71(7) of the Act. A contrario, the penalty should not be imposed on an entity that submits an application for any type of vehicle registration. It was the will of the legislator to include within the scope of the provisions of the Act on Road Traffic Law all cases of vehicle registration on the territory of the country"5.

In Authors' opinion, the above position should be considered as a correct one, as we cannot accept an application of a broad interpretation of provisions allowing for the imposition of sanctions. If the legislator wished to differentiate between the types of registration, he/she should explicitly indicate that in the Act.

It should be noted that a possibility of imposing a penalty is related to a failure to register a vehicle itself and it doesn't concerns an issue of a vehicle registration card, a vehicle card, registration plates, a verification mark, a control sticker, as these are activities of a material and technical nature ${ }^{6}$.

The second obligation (to notify about an acquisition or a disposal of a vehicle) is strictly a matter of an order ${ }^{7}$ and does not affect a validity of an acquisition or a disposal of a vehicle (e.g. sale, donation, or exchange).

The said obligations should be fulfilled within 30 days, which are calculated, respectively, from the date of transferring a vehicle (Article 71(7) of the RTL) or its purchase or sale (Article 78(2) of the RTL). The indicated deadline is a substantive law deadline and there is no possibility to restore it pursuant to Article $58-59$ of the $\mathrm{CAP}^{8}$. The last statement is important owing to the construction of sanctions related to the failure to fulfil the obligation.

5 Judgment of the Voivodeship Administrative Court in Poznań of 17 February 2021, II SA/Po 436/20 (CBOSA).

6 Judgment of the Voivodeship Administrative Court in Szczecin of 10 October 2019, II SA/Sz 753/19 (CBOSA), judgment of the Voivodeship Administrative Court in Lublin of 7 June 2018, III SA/Lu 138/18 (CBOSA), judgment of the Voivodeship Administrative Court in Bydgoszcz of 11 July 2016, II SAB/Bd 28/16 (CBOSA).

7 Judgment of the Voivodeship Administrative Court in Gorzów Wielkopolski of 8 May 2014, II SA/Go 237/14 (CBOSA).

8 B. Adamiak [in:] B. Adamiak, J. Borkowski, Kodeks postępowania administracyjnego. Komentarz do art. 58, Warszawa 2021. 


\section{Administrative monetary penalty}

Until 1 January 2020, in principle, no legal consequences were connected with a failure to fulfil the above-discussed obligations. The possibility of applying a criminal sanction from Article 97 of the Code of Offences ${ }^{9}$ was (and is) illusory, although it is formally permissible. Since 1 January 2020 an administrative sanction - i.e. an administrative fine - has been introduced for non-compliance with the indicated obligations incumbent upon the vehicle owner ${ }^{10}$. The fine was introduced as a result of the amendment of the Road Traffic Law by the Act of 19 July 2019 on amending the Act on maintaining cleanliness and order in municipalities and some other acts ${ }^{11}$, which added to the Act, inter alia, Article $140 \mathrm{mb}$ and Article 140n.

The basic objective of the amendment was to "contribute to the improvement of vehicle owners' compliance with the obligation to submit an application for the registration, deregistration of the vehicle within a specified deadline or the statutory deadline for notifying about the purchase, sale of the vehicle, or a change in the factual state, which requires the change of data in the registration certificate. In consequence, it should also improve the conditions for legal trade in vehicles and the referenceability of data collected in the central register of vehicles kept by a minister for informatization"12. Moreover, "the above amendments to the Act - the Road Traffic Law result from formal charges of the European Commission concerning a failure to comply with the obligations to transpose Directive 2000/53/EC of the European Parliament and of the Council of 18 September 2000 on end-of-life vehicles, concerning, inter

9 Act of 20 May 1971 - Code of Offences (consolidated text: Dz.U. of 2021, item 281 with subsequent amendments), further referred to as the CO.

10 For more details on the nature of this sanction T. Brzezicki, P. Rączka, J. Wantoch-Rekowski, Legal Aspects of the Imposition and Enforcement of an Administrative Penalty for Failure to Register a Vehicle Imported from the Territory of a European Union Member State, “Studia Iuridica Lublinensia” vol. XXX, 2, 2021, pp. 33-47.

11 Dz.U. of 2019, item 1579.

12 Government bill amending the Act on maintaining cleanliness and order in communes and some other acts. Print No. 3495 of 5 June 2019 r., https://www.sejm.gov.pl/ Sejm8.nsf/druk.xsp?nr=3495. 
alia, the lack of sanctions for non-registration of an imported vehicle and non-registration of an end-of-life vehicle. The Commission took the view that the Republic of Poland had failed to ensure the effective application of Articles 5(2) and 6(1) of Directive 2000/53/EC, and had therefore failed to fulfil its obligations under Article 4(3) of the Treaty on European Union by failing to penalize any infringement of the obligations to register a vehicle imported into Poland and to inform the competent authorities of the acquisition or disposal of the vehicle within 30 days"13.

A priori, it can be concluded that the existing sanctions were not sufficient to ensure the correct implementation of existing registration obligations $^{14}$.

\section{Form of the sanction and competent authority}

There is no doubt that a financial penalty is imposed by way of an administrative decision (Article 140n(1) of the RTL). In this respect, the legislator did not create a special mode of action of a public administration body for imposing a sanction. It decided unequivocally that sanction is a well-known construction of an administrative act issued by way of a general administrative procedure. The adopted solution seems to be optimal both for a person obliged to fulfil an obligation and for systemic reasons.

The application of the provisions of the Code of Administrative Procedure provides a party to the proceedings with broad procedural guarantees regarding its active participation in the proceedings, as well as a possibility of appealing against the issued decision. From the systemic point of view, it should be noted that an issued decision is subject to control at the instance body in case of an appeal, and also its legality may be verified by an administrative court as a result of a complaint or a cassation

\footnotetext{
Ibidem.

14 More broadly on the functions of an administrative sanction P. Czop, Sankcja administracyjna a wolność jednostki [in:] J. Zimmermann (ed.), Wolność w prawie administracyjnym, Warszawa 2017, pp. 136-138.
} 
appeal. The penalty is imposed by the starost (Article 140n(2a) RTL), while the appeal is considered by the local government appeals board (Article 17(1) CAP).

\section{The amount of a penalty and its moderation}

The legislator has specified a bracket system for a calculation of an amount of a penalty. The penalty imposed may not be lower than PLN 200 and may not exceed PLN 1,000. The introduced solution leaves the authority with some freedom regarding setting the amount of the penalty within the framework of the binding legal regulation. The penalty should be measured using statutory criteria, which include: 1) the scope of the infringement, 2) the repetitiveness of the infringement and 3) the financial benefits obtained by virtue of the infringement of the Act (Article 140n(4) RTL).

This means that the public administration body when imposing a penalty should carry out an explanatory proceeding aimed at determining in what circumstances an infringement was committed and what consequences commitment entails. Undoubtedly, as far as the penalty is concerned, practices employed by the body imposing the penalty will be important. Of course, the imposed penalty will be individualized and inseparably connected with the factual state of the particular case. However, it should not be forgotten that public administration bodies do not deviate from the established practice of resolving matters in the same factual and legal state without a justified reason (Article $8(2)$ of the CAP). Situations related to the discussed issues, which constitute the basis for imposing an administrative fine, will in most cases be of a typified nature, which will be connected, for example, with a lack of a legal awareness of the obliged entity or certain fortuitous situations (e.g. an illness of an individual) or simply a forgetfulness. It is likely that in the future public administration bodies will develop a common practice related to the quantification of penalties, which will be verified by the jurisprudence of administrative courts. When 
analysing current (relatively limited) jurisprudence, one may conclude that the number of days in breach of the obligation is the basic factor influencing the amount of the penalty. This is exemplified by the situation in the Voivodeship Administrative Court in Gorzów Wielkopolski case where "the authority indicated that in order to achieve the goal of transparency of adjudicating on the amount of penalties in the event of non-compliance with the obligation referred to in Article 78(2)(1RTL), a practice of adjudicating has been introduced, whereby a specific number of days in excess of the obligation was assigned an appropriate amount of the fine. Thus, if a number of days from 91 to 180 days was exceeded, the fine amounts to PLN 600. In the course of the proceedings it has been established that the scope of the infringement totals 126 days”" ${ }^{\text {. }}$

It is also indicated that a type of an activity conducted by an obliged party and a frequency of an infringement also have an impact on an amount of a penalty. In this instance, a situation in the case resolved by the Voivodeship Administrative Court in Warsaw should be indicated where it was noted that: "This is already the eighth infringement of this type by the applicant resulting from the failure to timely report the purchase or sale of a vehicle, as well as the lack of financial benefit from it, which, in the opinion of the authority, justified imposition of a fine in the amount of PLN 400.00. The applicant's company is a professional participant in commercial trade dealing in wholesale and retail sale of cars; it is the entrepreneur that is burdened with the negative consequences of negligence, omission or deliberate action resulting in administrative liability" ${ }^{16}$. The Voivodeship Administrative Court in Olsztyn, on the other hand, accepted that a lack of a financial benefit for an obliged party may also be a base for reducing a penalty, stating that "Since the adjudicating authorities established that the infringement in question is the first by the applicant and the party did not obtain any financial benefit from the infringement, and the only consequence of the

15 Judgment of the Voivodeship Administrative Court in Gorzów Wielkopolski of 9 June 2021, II SA/Go 170/21 (CBOSA).

16 Judgment of the Voivodeship Administrative Court in Warsaw of 24 February 2021, VII SA/Wa 2139/20 (CBOSA). 
infringement is exceeding the deadline for notifying about the disposal of the vehicle, which is equivalent to obtaining data that the authority undoubtedly already has from the obliged party, the imposition of a penalty at the level of half of its permissible limits should be deemed disproportionate to the gravity of the infringement" ${ }^{\text {17 }}$.

The analysis of the case-law leads to the conclusion that an amount of a penalty should be individualized in a particular situation, and it is not possible to apply the principle of automatism. Therefore, it is unacceptable for an authority to impose a penalty without taking into an account circumstances of a specific case.

\section{A possibility of waiving an administrative fine}

Some practical doubts in terms of imposing the discussed fine will be raised by a possibility to refrain from imposing an administrative fine, i.e. an institution regulated in Article 189f(1) of the CAP. Public administration bodies argued that "as a result of the reference contained in Article 140n(6) of the RTL to the proper application of the provisions of Section III of the Tax Ordinance, it was not possible to apply Article 189a(1) and (2) and Article 189f(1) of the CAP." ${ }^{\prime 18}$. The judicature has uniformly accepted that "by introducing Section IVa of the CAP, the legislator provided for the following legal construction - the provisions of this section are applicable to all administrative fines defined above, provided that there are no specific regulations in separate provisions" ${ }^{\text {. }}$. The possibility of using the institution of waiving the penalty should be considered valid. It allows an authority to refrain from imposing a financial penalty in specific situations, where a lack of possibility of fulfilling an obligation re-

17 Judgment of the Voivodeship Administrative Court in Olsztyn of 2 February 2021, II SA/Ol 947/20 (CBOSA).

18 Judgment of the Voivodeship Administrative Court in Gorzów Wielkopolski of 9 June 2021, II SA/Go 170/21 (CBOSA).

19 Ibidem, also a judgment of the Voivodeship Administrative Court in Warsaw of 7 April 2021, VII SA/Wa 2261/20 (CBOSA). 
sulted from objective circumstances which were caused by reasons beyond a control of an obliged party, or where imposing a penalty is not justified for social reasons. The above statement results from a fact that a public administration body, by way of a decision, refrains from imposing an administrative fine and issues a caution if 1) a gravity of an infringement of the law is negligible and a party has ceased to infringe the law or 2) for the same behaviour by a legally valid decision an administrative monetary penalty has been previously imposed on a party by another authorized public administration body or a party has been legally punished for a misdemeanour or a fiscal misdemeanour, or legally sentenced for a criminal offence or a fiscal offence and previous penalty fulfils purposes for which the administrative monetary penalty was to be imposed (Article 189f(1) of the CAP) ${ }^{20}$.

The Voivodeship Administrative Court in Łódź considered as justified for an application of the institution of waiving a penalty a situation in which information about a sale of a vehicle was made with “one day's delay, while at the same time the buyer performed the obligation to notify about the purchase of the vehicle and to register it, which is not negligible. It is difficult to accept the view of the authority that the applicant's compliance with the obligation to notify the sale of the vehicle one day after the expiry of the time-limit caused significantly adverse effects in the field of legally protected rights, if such effects can be discerned at all. This is because the obligation on the owner of a vehicle to notify of its sale or purchase is aimed at preventing situations in which, despite a transfer of ownership of the vehicle, the vehicle is still registered in the name of the

20 More broadly: S. Dudziak, Zasady wymiaru administracyjnych kar pieniężnych po nowelizacji Kodeksu postępowania administracyjnego, "Samorząd Terytorialny" 2018, No 6, pp. 23-32, A. Cebera, J.G. Firlus [in:] H. Knysiak-Sudyka (ed.), Kodeks postępowania administracyjnego. Komentarz, ed. II, Warszawa 2019, Art. 189(f), P.M. Przybysz [in:] Kodeks postępowania administracyjnego. Komentarz aktualizowany, LEX/el. 2021, Art. 189(f); A. Wróbel [in:] M. Jaśkowska, M. Wilbrandt-Gotowicz, A. Wróbel, Komentarz aktualizowany do Kodeksu postępowania administracyjnego, LEX/el. 2021, Art. 189(f). 
seller and it is the seller who is entered in the Central Register of Vehicles and in other official documents as the owner of the vehicle"21.

Furthermore, the judicature sees a possibility of applying a waiver when it is linked to a state of health of an obliged party, stating that "It is by no means the case that the individual circumstances relating to the pandemic situation (the duration of which cannot be measured merely in formal periods) and the state of health and the applicant's life situation are not relevant to the outcome of the matter".

A possibility of waiving an imposition of penalties should be considered as a correct solution, since a purpose of the introduction of provisions concerning administrative fines was to depart from an excessively rigorous and extremely formalistic application of administrative law norms. Strictly objectivized administrative liability was often incompatible with the sense of justice and the principles of social co-existence.

A lack of a possibility of applying an institution of a waiver of a penalty would also not be counterbalanced by the right to apply relief in payment of an administrative penalty through appropriate application of the provisions of Section III of the Act of 29 August 1997 - Tax Ordinance (Article 140n RTL).

\section{Criminal liability}

As regards persons other than natural persons, from a formal point of view it is possible to make use of provisions of the Code of Offences ${ }^{22}$ in an event of a failure to comply with obligations in question.

Prima facie, a criminal responsibility resulting from a lack of fulfilment of registration duties incumbent upon an owner of a vehicle, as provided for in Article 78(2) of the RTL, allows to apply a criminal sanction provided for in Article 97 of the Penal Code. It should be considered whether there exists a relation between the record keeping obligations in question and road traffic safety and order.

\footnotetext{
21 Judgment of the PAC in Łódź of 15 December 2020, III SA/Łd 603/20 (CBOSA).

22 Act of 20 May 1971 - Code of Offence (consolidated text: Dz.U. [Polish Journal of Laws] of 2021, poz. [item] 2008), further referred to as the CO.
} 
The legal norm contained in the provision of Article 97 of the Code of Offences is of a typical delegation nature owing to the "factual impossibility of including, within the provisions of the Code of Offences, all possible violations of, first of all, road traffic safety and order" ${ }^{23}$. This means that the constituent elements of an offence should be sought in other provisions of the Road Traffic Law Act or regulations issued on its basis, which concern safety or order in traffic, and must also refer to public roads, traffic zones or residential areas.

The principal offences in this area are concretized in the preceding articles, i.e. Articles 84-96 of the Code of Offences, while Article 97 is a supplementary (and not a substitute) provision. The aforementioned provision of the CO has been in force since 2 September 2010 as amended by Article 4(9) of the Act of 22 July 2010 amending the Road Traffic Law Act and certain other acts ${ }^{24}$. "In the wording of the provision prior to the last amendment, only a violation of provisions concerning safety or order of traffic on public roads could lead to realization of the elements of the offence under Article 97 of the CO. At present, the provision refers to a violation of other provisions of the Road Traffic Law or regulations issued on its basis. This could lead to the conclusion that the legislator's intention was to broaden the field of penalization by resignation from this previous requirement”25. However, when interpreting Article 97 of the CO it should be noted that this regulation has been included in the Code of Offences, in the chapter concerning offences against traffic safety and order not without reason. This means that despite amending the provision and the change of its wording, in order to fulfil the elements of the offence there still must be an infringement of such provisions of the Traffic Law or other provisions issued on its basis which concern road safety and order. In the judgment of the Supreme Court of 11 October 2000, IV KKN 250/00 we find that "the word «other» should - as indicated in the doc-

23 M. Leciak [in:] P. Daniluk (ed.), Kodeks wykroczeń. Komentarz, Warszawa 2016, Art. 97, p. 685.

24 Dz.U. No. 152, poz. 1018 with subsequent amendments.

25 A. Michalska-Warias [in:] T. Bojarski (ed.), Kodeks wykroczeń. Komentarz aktualizowany, LEX/el. 2021, Art. 97. 
trine - be understood in such a way that these should be regulations other than those specified in Articles 84-96a of the CO, while at the same time they must pertain to road traffic safety and order". The previous wording of the provision supports a conviction that "a specific offence cannot be separated from the object of protection - and in this case the object of protection is safety and order in road traffic. Without the application of a wider interpretation (which is of course prohibited) it is difficult to link the act under Article 78(2) of the Road Traffic Law with a direct violation of safety and order in road traffic" ${ }^{26}$.

"The Code of Offences lists a number of provisions defining offences against traffic safety and order, the occurrence of which does not require posing any kind of a danger, or sometimes even creating such a possibility - an abstract situation, lacking practical reality. These are formal offences, without consequences, the subject of which may be anyone, not only the driver. The rationale for introducing a punitive regime for this type of a behaviour may give rise to serious reservations”27. Therefore, when interpretation of the provision of Article 97 of the $\mathrm{CO}$ results in finding that the offence is of a formal character, it means that the legislator does not stipulate the necessity for a specific effect to occur. What is required here is a mere exhaustion of the elements of the offence set out in the provision. Additionally, "an offence may be committed as a result of an act or omission (in those cases where the provision of another act imposes an obligation to behave in a specific way). In order for a given behaviour to be considered an offence as stipulated in Article 97 of the CO, it must be committed on a public road, in a residential zone or in the traffic zone (...) when the offender is a road user or another person. However, when the offender is the owner or holder of the vehicle, the Act does not define in any way the place of committing the offence" ${ }^{28}$.

26 A. Mezglewski, M. Nowikowska, J. Kurek [in:] Prawo o ruchu drogowym. Komentarz, Legalis, 2020, Art. 97.

27 J.K. Pawelec (ed.), Wypadki i inne zdarzenia drogowe. Opiniowanie w sprawach rekonstrukcji, LEX.

28 A. Michalska-Warias [in:] T. Bojarski (ed.), Kodeks Wykroczeń. Komentarz, Warszawa 2015, Art. 97, p. 383. 
The offence provided for in Article 97 of the $\mathrm{CO}$ is punishable by a fine from PLN 20 to PLN 3,000 or a reprimand. The penalty of a reprimand may be applied when an adjudicating authority decides that it is sufficient for an offender to respect the law and the rules of social coexistence, taking into consideration his/her personal conditions as well as a nature and circumstances of the act. For the same reasons, the authority may apply an extraordinary mitigation of the penalty or, alternatively, refrain from imposing the penalty altogether, as the penalty under this provision is not obligatory at all. Pursuant to Article 39(4) of the CO, in case of discharging an offence, it is possible to take a measure of social impact towards the offender, aimed at restoring the breached legal order or redressing the harm caused, consisting in particular in an apology to the wronged party, a solemn declaration not to commit such an act again or a commitment of the offender to restore the previous state of affairs. As it is well known, "the penalty (...) for a petty offence is not intended to be a mere retribution for the act committed and for the harm or damage caused by the offender, but is intended to achieve the assumed socially useful objectives"29.

Finally, it should be noted that pursuant to Article 140n of the RTL "if the act constituting the infringement referred to in Article $140 \mathrm{mb}$ also meets the characteristics of an offence, only the provisions on administrative liability are applicable to an entity that is a natural person"30.

To conclude, the legislator has not thoroughly reflected a legitimacy of an application of a penal sanction under Article 97 of the $\mathrm{CO}$ in conjunction with Article 78(2) of the RTL owing to the fact that the mere absence of a vehicle registration does not in itself constitute a violation of traffic safety and order. In fact, the behaviour in question is not even directly related to a road traffic. "It should be noted that, as a matter of fact, such conceptual categories as road traffic safety and traffic order are imprecise, hence imposing on trial authorities the obligation to decide, on

29 V. Konarska-Wrzosek, A. Marek, T. Oczkowski, Podstawy prawa karnego i prawa wykroczeń, Toruń 2013, p. 114.

30 Act of 20 June 1997 - Road Traffic Law (consolidated text, Dz.U of 2021, poz. 450 with subsequent amendments). 
a case-by-case basis, whether the infringement of a particular provision of the Road Traffic Law Act or a legal act issued on its basis which directly threatened road traffic safety and/or traffic order poses a risk of overly arbitrary decisions" ${ }^{\prime 3}$. The conclusion can be drawn that the provision of Article 97 of the CO is in fact superfluous, because a penal sanction is not applicable in case of an infringement of registration obligations and in order to apply it, the authority should carry out administrative proceedings resulting in the issuance of a decision on imposing an administrative fine. The obligation resulting from Article 78(2) of the RTL has a purely organizational character and has no direct impact on the safety and order in traffic.

\section{Conclusion}

The implemented measure gives the registration authorities (starosts) a possibility of penalizing under administrative law entities which do not fulfil their registration obligations. Prima facie, existing regulations make it possible to apply both an administrative sanction in the form of an administrative fine, and a criminal sanction.

Unfortunately, there are still legal doubts about a possibility of applying punitive sanctions to entities other than natural persons. According to the authors, it is impossible to apply such sanctions. A de lege ferenda postulate is to directly introduce in the RTL an exclusion of criminal responsibility when an entity does not perform vehicle registration obligations professionally and the non-performance doesn't constitute a direct threat to road traffic safety.

The introduction of an administrative sanction deserves endorsement, because administrative liability, as a rule, is objectivized. This means that imposing a penalty is possible when statutory prerequisites are fulfilled and the culpability of an obliged entity is of secondary nature. However, this liability is not absolute. The already established view of administra-

31 M. Leciak [in:] P. Daniluk (ed.), Kodeks wykroczeń. Komentarz, Warszawa 2016, Art. 97, p. 685. 
tive courts that it is possible to waive the imposition of an administrative fine on the basis of the provisions of the CAP should be regarded as correct. The latter is of systemic nature and one should hope that such a trend in case law (allowing for an application of an institution of waiving the imposition of a fine) will have its application in relation to other administrative fines as well.

\section{Bibliography:}

Adamiak B. [in:] B. Adamiak, J. Borkowski, Kodeks postępowania administracyjnego. Komentarz do art. 58, C.H. Beck, Warszawa 2021.

Brzezicki T., Rączka P., Wantoch-Rekowski J., Legal Aspects of the Imposition and Enforcement of an Administrative Penalty for Failure to Register a Vehicle Imported from the Territory of a European Union Member State, “Studia Iuridica Lublinensia” vol. XXX, 2, 2021, pp. 33-47.

Cebera A., Firlus J.G. [in:] H. Knysiak-Sudyka (ed.), Kodeks postępowania administracyjnego. Komentarz, ed. II, Wolters Kluwer, Warszawa 2019, Art. 189(f).

Czop P., Sankcja administracyjna a wolność jednostki [in:] J. Zimmermann (ed.), Wolność w prawie administracyjnym, Wolters Kluwer, Warszawa 2017.

Dudziak S., Zasady wymiaru administracyjnych kar pieniężnych po nowelizacji Kodeksu postępowania administracyjnego, „Samorząd Terytorialny” 2018, No 6, pp. 23-32.

Konarska-Wrzosek V., Marek A., Oczkowski T., Podstawy prawa karnego i prawa wykroczeń, TNOiK, Toruń 2013.

Leciak M. [in:] P. Daniluk (ed.), Kodeks wykroczeń. Komentarz, C.H. Beck, Warszawa 2016.

Malinowski Ł. [in:] Prawo o ruchu drogowym. Komentarz, Warszawa 2012, Art. 72, Thesis 11, eLex.

Mezglewski A., Nowikowska M., Kurek J. [in:] A. Mezglewski, M. Nowikowska, J. Kurek, Prawo o ruchu drogowym. Komentarz, Legalis, 2020, Art. 97.

Michalska-Warias A. [in:] T. Bojarski (ed.), Kodeks wykroczeń. Komentarz aktualizowany, LEX/el. 2021, Art. 97.

Michalska-Warias A. [in:] T. Bojarski (ed.), Kodeks Wykroczeń. Komentarz, Wolters Kluwer, Warszawa 2015. 
Pawelec J.K. (ed.), Wypadki i inne zdarzenia drogowe. Opiniowanie w sprawach rekonstrukcji, LEX.

Przybysz P.M. [in:] Kodeks postępowania administracyjnego. Komentarz aktualizowany, LEX/el. 2021, Art. 189(f).

Stahl M., Lewicka R., Lewicki M. (eds.), Sankcje administracyjne. Blaski i cienie, Wolters Kluwer, Warszawa 2011.

Wincenciak M., Sankcje $w$ prawie administracyjnym i procedura ich wymierzania, Wolters Kluwer, Warszawa 2008.

Wróbel A. [in:] M. Jaśkowska, M. Wilbrandt-Gotowicz, A. Wróbel, Komentarz aktualizowany do Kodeksu postępowania administracyjnego, LEX/el. 2021, Art. 189(f). 